LONG-TERM EFFECTS OF DREDGING OPERATIONS PROGRAM

US Army Corps of Engineers
MISCELLANEOUS PAPER D-85-2

\section{BIOACCUMULATION AND EFFECTS ON REPRODUCTION IN AQUATIC ORGANISMS: AN ASSESSMENT OF THE CURRENT LITERATURE \\ by}

T. M. Dillon, A. B. Gibson

Environmental Laboratory

DEPARTMENT OF THE ARMY

Waterways Experiment Station, Corps of Engineers PO Box 631, Vicksburg, Mississippi 39180-0631
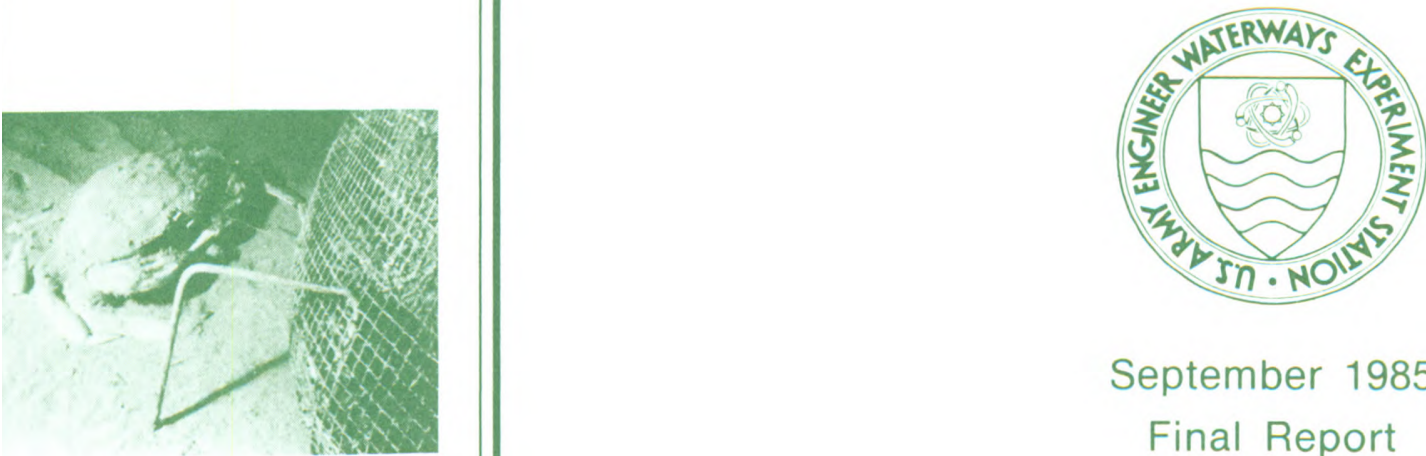

September 1985

Final Report

Approved For Public Release: Distribution Unlimited

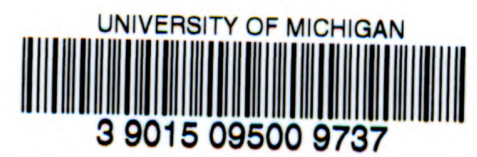

Prepared for DEPARTMENT OF THE ARMY US Army Corps of Engineers Washington, DC 20314-1000

Under Work Unit 31773 